\title{
Schurer operators of King type
}

\section{Petru I. BraicA, Ovidiu T. Pop and DAN BĂRbosu}

\section{ABSTRACT.}

A class of linear and positive operators defined by finite sum which generalizes the classical Schurer's operators in the King sense is constructed. For the mentioned class of operators, uniform convergences results, error estimations in terms of modulus of continuity and Voronovskaja type theorems are established.

\section{REFERENCES}

[1] Agratini, O., An asymptotic formula for a class of approximation processes of King's type, Studia Sci. Math. Hungar., 47 (2010), No. 4, 435-444

[2] Bărbosu, D., Introduction in numerical analysis and approximation theory, Ed. Univ. de Nord Baia Mare, 2009 (in Romanian)

[3] Braica, P. I., Pop, O. T. and Indrea, A. D., About a King-type operator, Appl. Math. Inf. Sci., 6 (2012), No. 1, 145-148

[4] King, J. P., Positive linear operators which preserve $x^{2}$, Acta Math. Hungar., 99 (2003), No. 3, 203-208

[5] Oancea, I., J. P. King version of Schurer operator, Journal of Science and Arts, 1 (2009), 43-49

[6] Pop, O. T., The generalization of Voronovskaja's theorem for a class of linear and positive operators, Rev. Anal. Numer. Théor. Approx., 34 (2005), No. 1, 79-91

[7] Schurer, F., Linear positive operators in approximation theory, Math. Inst. Tech., Univ. Delft. Report, 1962

[8] Stancu, D. D., Coman, Gh., Agratini, O. and Trîmbiţaş, R., Numerical analysis and approximation theory, I, Presa Universitară Clujeană, ClujNapoca, 2001 (in Romanian)

SECONDARY SCHOOL "GRIGORE MOISIL"

Mileniului 1, 440037 SATU MaRe, Romania

E-mail address: petrubreyahoo.com

National College "Mihai Eminescu"

MIHAI EMINESCU 5, 440014

SATU MARE, ROMANIA

E-mail address: ovidiutiberiu@yahoo.com

DePartMent of MATHEMATICS AND COMPUTER SCIENCE

FACULTY OF SCIENCES

NORTH University CENTER AT BAIA MARE

TECHNICAL UNIVERSITY OF CLUJ-NAPOCA

Victoriei 76, 430122 BAIA MARE, ROMANIA

E-mail address: barbosudan@yahoo.com

* Dedicated to Professor Emeritus Constantin Corduneanu on the occasion of his 85th birthday Received: 25.06.2013; In revised form: 30.08.2013; Accepted: 03.09.2013

2010 Mathematics Subject Classification. 41 A10, 41A63.

Key words and phrases. Schurer operators, Voronovskaja type theorem, King type operators, modulus of continuity. 